\title{
Impact of Intensity and Exposure Duration of Magnetic Field on Seed Germination of Tomato (Lycopersicon esculentum L.)
}

\author{
Hassan FEIZI ${ }^{1 *}$, Hossein SAHABI ${ }^{2}$, Parviz REZVANI MOGHADDAM ${ }^{1}$, Nasser \\ SHAHTAHMASSEBI ${ }^{3}$, Omran GALLEHGIR ${ }^{4}$, Shahram AMIRMORADI' \\ ${ }^{1}$ Ferdowsi University of Mashhad, Faculty of Agriculture, Agronomy Department, Mashbad, Iran; hasanfeizi@yahoo.com ('corresponding author) \\ ${ }^{2}$ Torbat Heydarieh Technical and Engineering Faculty, Torbat Heydarieh, Iran \\ ${ }^{3}$ Ferdowsi University of Mashhad, Faculty of Sciences, Physics Department, Mashhad, Iran \\ ${ }^{4}$ Payame Noor University, Department of Agriculture, Genaveh, Iran
}

\begin{abstract}
In order to study the effect of seed hydro priming and magnetic field on tomato seed germination an experiment was conducted in laboratory of Ferdowsi University of Mashhad, Iran, in 2010. The experimental treatments were all combinations of two levels of hydro priming (use of dry seed and soaked seed for five h in distilled water) and eight levels of magnetic field treatments (pretreatment of seeds in $15 \mathrm{mT}$ for 5, 15 and 25 minutes, pretreatment of seeds in $25 \mathrm{mT}$ for 5, 15 and 25 minutes, continuous magnetic field with $3 \mathrm{mT}$ and control) with four replications. Results indicated that hydro priming of seeds reduced mean germination time significantly. Root length increased by 14 percent in seed hydro priming treatment in comparison with dry seed treatment. Shoot length, seedling length and vigor index of hydro primed seeds increased by 7, 12 and 13 percent, respectively compared with dry seeds. Exposure of seeds with 3 mT continuous magnetic field and $25 \mathrm{mT}$ for $5 \mathrm{~min}$ increased root length by 29 and 25 percents, respectively in comparison with control. The highest shoot length, seedling length and vigor index were obtained in $3 \mathrm{mT}$ continuous magnetic field and $25 \mathrm{mT}$ for $5 \mathrm{~min}$.
\end{abstract}

Keywords: mean germination time, magnetic field, seedling length, seed treatment, vigor index

\section{Introduction}

Tomato (Lycopersicon esculentum L.) is a widely consumed worldwide vegetable either raw or after processing. In 2009, Khorasan Razavi province tomato cultivation area represented $9 \%$ of the 161800 ha (total fresh market production 5.9 million tone) of Iran (Anonymous, 2007). It was cultivated on 161800 ha and the production was 5.9 million tones in 2009. In Iran, Khorasan Razavi province is one of the greatest tomato producers with cultivating area about 14000 ha (Anonymous, 2007). In some areas of this province, tomato is cultivated as direct seeding in main field in spring. Weak germination and emergence in direct seeding is the main problem in the field. Therefore, improvement of seed germination and emergence affected on better crop establishment in the field and reduce production costs.

These days' sustainable agricultural systems around the world try to find out environmental friendly technologies based on physical and biological treatments to increase the seedling vigor, crop establishment and crop production. Using magnetic fields as a physical treatment to increase seed germination and emergence is one of the safe and reasonable methods in crop production systems (Vashisth and Nagarajan, 2010).
The mechanism of the effect of static magnetic field on physiological characteristics of plants is not clear, yet. Plant species responses to magnetic field are unpredictable. Their response depends on magnetic field intensity, the time of exposure to magnetic field, seed priming methods and species (Dhawi et al., 2009). It has been stated that positive effect of magnetic treatment may be due to paramagnetic properties of some atoms in plant cells and pigments such as chloroplasts (Aladjadjiyan, 2010). Magnetic properties of molecules determine their ability to attract and then change the energy of magnetic field in other type of energy and to transfer this energy afterward to other structures in plant cells, thus activating them (Aladjadjiyan, 2010). In an experiment, Racuciu et al. (2006) showed that the exposure of maize seeds to low static magnetic field (50 $\mathrm{mT}$ ) had the stimulatory influence on the plants in their early growth stages, enhancement of the fresh weight, assimilatory pigments level as well as the chlorophyll ratio, average nucleic acids level, and increase of the seedling length. Higher magnetic field induction (ranging between 100 and $250 \mathrm{mT}$ ) had an inhibitory effect on all measured traits.

Florez et al. (2007) reported that the germination and early growth of maize seedlings were improved when seeds were exposed to continuously stationary magnetic fields. 
Vashisth and Nagarajan (2008) stated significant increases in germination percent, seedling vigor and shoot/root growth of chickpea seeds exposed to static magnetic fields. They also added that magnetic fields increased seedling dry weights of 1-month-old chickpea plants. De Souza et al. (2006) reported electromagnetic treatments led to a significant increase in leaf area, leaf dry weight, mean fruit weight, the fruit yield per plant, and the fruit yield of tomato per area. Celestino et al. (2000) demonstrated that germination and growth of Quercus suber seedlings increased when exposed to continual electromagnetic field. Harichand et al. (2002) reported that exposure of seeds to magnetic field $(10 \mathrm{mT} ; 40 \mathrm{~h})$ increased plant height, seed weight per spike and yield of wheat.

Garcia Reina et al. (2001) indicated that treated lettuce seeds by magnetic field $(10 \mathrm{mT}$ for $10 \mathrm{~min}$ ) absorbed more water and quicker than untreated seeds. Cakmak et al. (2009) reported that the higher seed germination and growth rates of bean and wheat plants were obtained when the seeds were exposed to permanent $7 \mathrm{mT}$ magnetic field.

Podlesny et al. (2004) confirmed the positive effect of magnetic treatments on germination and emergence of broad bean. They found that plant emergence was occurred 2-3 days earlier in magnetic treatments compared with control. They also added that magnetic treatment of broad bean seeds prior to sowing significantly increased seed yield. Martínez et al. (2009) indicated that germination rate and first stages of growth of tomato seedlings were increased but mean germination time (MGT) was significantly reduced compared to control when tomato seeds were exposed to magnetic field. It has been reported that maize seeds exposed to a $150 \mathrm{mT}$ magnetic field encouraged shoot development and led to increase of the germination, fresh weight and shoot length (Aladjadjiyan, 2002).

Numerous farmers cultivate tomato as direct seeding. Thus improvement of germination and emerging traits of tomato seed contribute to earlier and better field establishment that lead to reduction of seed consumption and production costs. This approach may be benefit in nursery where seeds germinate and grow for 1-2 month and then transplant to main field. The aim of the research undertaken was to determine the influence of the magnetic treatment and hydro priming of seeds on germination traits of tomato seeds.

\section{Materials and methods}

\section{Experimental design and data observation}

In order to study the effect of hydro priming and magnetic field on tomato germination, a randomized completely design with four replications was used. The experimental treatments were all combinations of two levels of hydro priming (use of dry seed and soaked seed for five $h$ in distilled water) and eight levels of magnetic field treat- ments (pretreatment of seeds in $15 \mathrm{mT}$ for 5,15 and 25 minutes, pretreatment of seeds in $25 \mathrm{mT}$ for 5,15 and 25 minutes, continuous magnetic field with $3 \mathrm{mT}$ and control). The Experiment was conducted in with natural light and an average temperature of $24^{\circ} \mathrm{C}$ at laboratory of College of Agriculture, Ferdowsi University of Mashhad, Iran in 2010. Magnetic treatments were realized by exposing seeds based on defined magnetic field for different times. Magnetic field induced by two permanent magnet with dimensions $2.8 \times 10.9 \times 8.4 \mathrm{~cm}(25 \mathrm{mT})$ and $2.5 \times 5 \times 2.3$ $\mathrm{cm}(15 \mathrm{mT})$. For exert the continuous magnetic field on seeds, it has been used magnetic tape pieces $(1 \times 5 \mathrm{~cm})$ with $3 \mathrm{mT}$ strength and labeled them below each petri dish with $1 \mathrm{~cm}$ space from each other. 25 seeds were placed on filter paper (Whatman paper No.1001110 with $9 \mathrm{~cm}$ diameter) soaked with distilled water $(8 \mathrm{ml}$ in each petri dish). Therefore, groups of 100 seeds were subjected to each magnetic treatment and similar groups were used as control. Germination tests were performed according to the rule issued by the International Seed Testing Association (ISTA, 2009). All magnetic fields and control ran at the same time, and consequently, under equal light and temperature conditions. Number of germinated seeds was noted daily for 14 days. Seeds were considered as germinated when their radicle showed at least $2 \mathrm{~mm}$ (ISTA, 2009). Mean germination time was calculated following Matthews and Khajeh-Hosseini (2007):

$$
M G T=\frac{\sum F X}{\sum F}
$$

where $F$ is the number of seeds newly germinating at time $\mathrm{X}$, and $X$ is days from sowing. Seedling vigor was calculated following Vashisth and Nagarajan (2010) as:

Vigor index $=$ Germination $\% \times$ Seedling length $($ Root + Shoot)

\section{Statistical analysis}

The data were analyzed using MSTAT-C software. For the laboratory experiment, analysis of variance (ANOVA) was performed on a factorial randomized completely design. The significant levels of difference for all measured traits among seed hydro priming, magnetic fields, duration of exposure and their interactions were calculated and the means compared by multiple range Duncan test among treatments for each trait.

\section{Results}

The treatments did not significantly affect on germination and normal seedlings (Tab. 1). Results indicated that both of experimental factors (seed hydro priming and magnetic field) had a significant effect on mean germination time (MGT), root length, shoot length, seedling length and vigor index of tomato seed (Tab. 2 and 3). Mean germination times were obtained 3.7 and 3.87 (days) in hydro primed seeds and dry seeds, respectively. Germination and 
118

normal seeds percentages were not affected by seed hydro priming (Tab. 2).

Although magnetic field had not any effect on final germination percent of tomato seeds but it had significant effect on mean germination time. The lowest MGT was obtained in continuous exposure of tomato seeds at $3 \mathrm{mT}$ magnetic field. MGT in continuous magnetic field was 2.51 whereas in control was 4.06 days. Moreover MGT in pretreatment of seeds by $15 \mathrm{mT}$ magnetic field for $25 \mathrm{~min}$ utes was achieved 3.72 days (Tab. 3). The highest Root, shoot and seedling length were achieved in $3 \mathrm{mT}$ continuous magnetic field treatment. Also the highest root and seedling length showed in exposure of seeds in $25 \mathrm{mT}$ magnetic field. Seedling length in continuous magnetic field treatment was the highest (11.33) while it was 10.64 in $25 \mathrm{mT}$ at 5 minutes treatment (Tab. 3).

The lowest MGT was obtained in both of hydro primed and dry seeds in $3 \mathrm{mT}$ continuous magnetic field (T7). Mean germination time was achieved 2.57 and 2.45 when hydro primed and dry seeds exposed to $3 \mathrm{mT}$ continuous magnetic field, respectively. The highest root length was observed in $3 \mathrm{mT}$ continuous magnetic field $(8.28 \mathrm{~cm})$ and $25 \mathrm{mT}$ at 5 minutes $(8.01 \mathrm{~cm})$. Also the greatest shoot length, seedling length and vigor index were observed in $3 \mathrm{mT}$ continuous magnetic field and $25 \mathrm{mT}$ at 5 minutes treatments (Tab. 4).

\section{Discussion}

\section{Seed hydro priming}

Results indicated that seed hydro priming had a significant effect on mean germination time (MGT), root length, shoot length, seedling length and vigor index of tomato seed (Tab. 2). Mean germination times were obtained 3.7 and 3.87 (days) in hydro primed seeds and dry seeds, respectively. Root length, shoot length, seedling length and vigor index increased by $14,7,12$, and 13 percentage, respectively in hydro primed seeds compared with dry seeds. Germination and normal seeds percentages were not affected by seed hydro priming (Tab. 2). Faqenabi $e t$ al. (2009) indicated that seed emergence percentage and grain yield of safflower increased by hydro priming.

\section{Magnetic field}

Although magnetic field had not any effect on final germination percent of tomato seeds, it had significant effect on mean germination time. The lowest MGT was obtained in continuous exposure of tomato seeds at $3 \mathrm{mT}$ magnetic field. Continuous magnetic field reduced MGT of tomato seeds by 62 percent compared with control. In addition pretreatment of seeds by $15 \mathrm{mT}$ magnetic field for 25 minutes decreased MGT about 30 percent (Tab. 3). Garcia Reina et al. (2001) demonstrated that lettuce

Tab. 1. Analysis of variance (mean of squares) of seed germination and seedling growth indices of tomato

\begin{tabular}{ccccccccc}
\hline Source of Variation & $\begin{array}{c}\text { Degree of } \\
\text { freedom }\end{array}$ & Germination & MGT & $\begin{array}{c}\text { Normal } \\
\text { seedling }\end{array}$ & $\begin{array}{c}\text { Root } \\
\text { length }\end{array}$ & $\begin{array}{c}\text { Shoot } \\
\text { length }\end{array}$ & $\begin{array}{c}\text { Seedling } \\
\text { length }\end{array}$ & $\begin{array}{c}\text { Vigor } \\
\text { index }\end{array}$ \\
\hline Hydropriming (a) & 1 & $6.25^{\text {ns }}$ & $0.50^{*}$ & $6.25^{\text {ns }}$ & $13.23^{*}$ & $0.50^{*}$ & $18.92^{*}$ & $185289^{*}$ \\
\hline Magnetic field (b) & 7 & $20.54^{\text {ns }}$ & $2.27^{\text {ns }}$ & $91.68^{\text {ns }}$ & $3.43^{*}$ & $0.74^{*}$ & $7.14^{*}$ & $59885^{*}$ \\
\hline $\mathrm{a}^{*} \mathrm{~b}$ & 7 & $43.39^{\text {ns }}$ & $0.17^{*}$ & $159.97^{\text {ns }}$ & $1.71^{*}$ & $0.23^{*}$ & $2.18^{*}$ & $22580^{\circ}$ \\
\hline Error & 48 & 64.06 & 0.15 & 315.52 & 1.12 & 0.07 & 1.28 & 17216 \\
\hline
\end{tabular}

In each column, ${ }^{* *}$ and ${ }^{*}$ shows significantly different at 5 and $1 \%$ probability levels, and ns is not significantly different

Tab. 2. Effect of tomato seed hydro priming on germination traits

\begin{tabular}{cccccccc}
\hline Treatment & $\begin{array}{c}\text { Germination } \\
\%\end{array}$ & $\begin{array}{c}\text { MGT } \\
(\text { day })\end{array}$ & $\begin{array}{c}\text { Normal } \\
\text { seedling\% }\end{array}$ & $\begin{array}{c}\text { Root length } \\
(\mathrm{cm})\end{array}$ & $\begin{array}{c}\text { Shoot } \\
\text { length }(\mathrm{cm})\end{array}$ & $\begin{array}{c}\text { Seedling } \\
\text { length }(\mathrm{cm})\end{array}$ & $\begin{array}{c}\text { Vigor } \\
\text { index }\end{array}$ \\
\hline Hydro priming & $92.6 \mathrm{a}^{*}$ & $3.7 \mathrm{~b}$ & $88.3 \mathrm{a}$ & $7.59 \mathrm{a}$ & $2.51 \mathrm{a}$ & $10.1 \mathrm{a}$ & $936.3 \mathrm{a}$ \\
Dry seed & $92 \mathrm{a}$ & $3.9 \mathrm{a}$ & $88.9 \mathrm{a}$ & $6.68 \mathrm{~b}$ & $2.34 \mathrm{~b}$ & $9.0 \mathrm{~b}$ & $828.7 \mathrm{~b}$ \\
\hline
\end{tabular}

${ }^{*}$ Means, in each column, followed by similar letter are not significantly different at the $5 \%$ probability level-using Duncan's Multiple Range Test

Tab. 3. Effect of magnetic field on germination traits of tomato seed

\begin{tabular}{ccccccccc}
\hline $\begin{array}{c}\text { Magnetic } \\
\text { field }(\mathrm{mT})\end{array}$ & $\begin{array}{c}\text { Time } \\
(\mathrm{min})\end{array}$ & $\begin{array}{c}\text { Germination } \\
(\%)\end{array}$ & $\begin{array}{c}\text { MGT } \\
(\mathrm{day})\end{array}$ & $\begin{array}{c}\text { Normal } \\
\text { seedling }(\%)\end{array}$ & $\begin{array}{c}\text { Root length } \\
(\mathrm{cm})\end{array}$ & $\begin{array}{c}\text { Shoot } \\
\text { length }(\mathrm{cm})\end{array}$ & $\begin{array}{c}\text { Seedling } \\
\text { length }(\mathrm{cm})\end{array}$ & $\begin{array}{c}\text { Vigor } \\
\text { index }\end{array}$ \\
\hline 15 & 5 & $94 \mathrm{a}^{*}$ & $3.87 \mathrm{ab}$ & $82 \mathrm{a}$ & $7.06 \mathrm{~b}$ & $2.39 \mathrm{bc}$ & $9.45 \mathrm{~b}$ & $890 \mathrm{bc}$ \\
15 & 15 & $90 \mathrm{a}$ & $4.17 \mathrm{a}$ & $86.5 \mathrm{a}$ & $6.89 \mathrm{~b}$ & $2.44 \mathrm{bc}$ & $9.34 \mathrm{~b}$ & $841 \mathrm{c}$ \\
15 & 25 & $92 \mathrm{a}$ & $3.72 \mathrm{~b}$ & $90 \mathrm{a}$ & $6.92 \mathrm{~b}$ & $2.40 \mathrm{bc}$ & $9.32 \mathrm{~b}$ & $855 \mathrm{bc}$ \\
25 & 5 & $90 \mathrm{a}$ & $3.92 \mathrm{ab}$ & $87.5 \mathrm{a}$ & $8.01 \mathrm{a}$ & $2.62 \mathrm{~b}$ & $10.64 \mathrm{a}$ & $958 \mathrm{ab}$ \\
25 & 15 & $91 \mathrm{a}$ & $4.11 \mathrm{a}$ & $88 \mathrm{a}$ & $6.73 \mathrm{~b}$ & $2.18 \mathrm{~cd}$ & $8.91 \mathrm{~b}$ & $814 \mathrm{c}$ \\
25 & 25 & $94 \mathrm{a}$ & $3.92 \mathrm{ab}$ & $92.5 \mathrm{a}$ & $6.79 \mathrm{~b}$ & $2.21 \mathrm{~cd}$ & $9.01 \mathrm{~b}$ & $852 \mathrm{bc}$ \\
3 & Contin. & $93 \mathrm{a}$ & $2.51 \mathrm{c}$ & $92 \mathrm{a}$ & $8.28 \mathrm{a}$ & $3.05 \mathrm{a}$ & $11.33 \mathrm{a}$ & $1057 \mathrm{a}$ \\
\hline Control & - & $93 \mathrm{a}$ & $4.06 \mathrm{ab}$ & $90 \mathrm{a}$ & $6.41 \mathrm{~b}$ & $2.10 \mathrm{~d}$ & $8.51 \mathrm{~b}$ & $793 \mathrm{c}$ \\
\hline
\end{tabular}

\footnotetext{
* Means, in each column, followed by similar letter are not significantly different at the $5 \%$ probability level-using Duncan's Multiple Range Test
} 
Tab. 4. Interaction effects of magnetic field and seed hydro priming on germination traits of tomato seed

\begin{tabular}{ccccccc}
\hline \multirow{2}{*}{ Treatment } & $\begin{array}{c}\text { MGT } \\
(\text { day })\end{array}$ & $\begin{array}{c}\text { Root length } \\
(\mathrm{cm})\end{array}$ & $\begin{array}{c}\text { Shoot length } \\
(\mathrm{cm})\end{array}$ & $\begin{array}{c}\text { Seedling length } \\
(\mathrm{cm})\end{array}$ & Vigor index \\
\hline \multirow{5}{*}{ Hydro primed seed } & $\mathrm{T}_{1}$ & $3.81 \mathrm{bcd}^{*}$ & $7.59 \mathrm{~b}$ & $2.47 \mathrm{bcde}$ & $10.06 \mathrm{bc}$ & $932 \mathrm{bc}$ \\
& $\mathrm{T}_{2}$ & $4.3 \mathrm{ab}$ & $7.03 \mathrm{~b}$ & $2.57 \mathrm{bc}$ & $9.60 \mathrm{bcd}$ & $894 \mathrm{~cd}$ \\
& $\mathrm{~T}_{3}$ & $3.47 \mathrm{~d}$ & $7.15 \mathrm{~b}$ & $2.40 \mathrm{bcde}$ & $9.55 \mathrm{bcd}$ & $864 \mathrm{~cd}$ \\
& $\mathrm{~T}_{4}$ & $3.66 \mathrm{~cd}$ & $9.35 \mathrm{~b}$ & $2.72 \mathrm{~b}$ & $12.07 \mathrm{a}$ & $1061 \mathrm{~b}$ \\
& $\mathrm{~T}_{5}$ & $3.89 \mathrm{abcd}$ & $7.20 \mathrm{~b}$ & $2.15 \mathrm{def}$ & $9.34 \mathrm{bcd}$ & $867 \mathrm{~cd}$ \\
& $\mathrm{~T}_{6}$ & $3.84 \mathrm{abcd}$ & $7.19 \mathrm{~b}$ & $2.07 \mathrm{ef}$ & $9.26 \mathrm{bcd}$ & $871 \mathrm{~cd}$ \\
& $\mathrm{~T}_{7}$ & $2.57 \mathrm{e}$ & $9.05 \mathrm{a}$ & $3.49 \mathrm{a}$ & $12.53 \mathrm{a}$ & $1214 \mathrm{a}$ \\
& $\mathrm{T}_{8}$ & $4.05 \mathrm{abc}$ & $6.19 \mathrm{~b}$ & $2.24 \mathrm{cdef}$ & $8.42 \mathrm{~d}$ & $788 \mathrm{~cd}$ \\
\hline \multirow{5}{*}{ Dry seed } & $\mathrm{T}_{1}$ & $3.94 \mathrm{abcd}$ & $6.53 \mathrm{~b}$ & $2.31 \mathrm{bcdef}$ & $8.84 \mathrm{bcd}$ & $848 \mathrm{~cd}$ \\
& $\mathrm{~T}_{2}$ & $4.05 \mathrm{abc}$ & $6.75 \mathrm{~b}$ & $2.32 \mathrm{bcdef}$ & $9.07 \mathrm{bcd}$ & $789 \mathrm{~cd}$ \\
& $\mathrm{~T}_{3}$ & $3.98 \mathrm{abc}$ & $6.69 \mathrm{~b}$ & $2.40 \mathrm{bcde}$ & $9.09 \mathrm{bcd}$ & $845 \mathrm{~cd}$ \\
& $\mathrm{~T}_{4}$ & $4.18 \mathrm{ab}$ & $6.68 \mathrm{~b}$ & $2.52 \mathrm{bcd}$ & $9.20 \mathrm{bcd}$ & $855 \mathrm{~cd}$ \\
& $\mathrm{~T}_{5}$ & $4.33 \mathrm{a}$ & $6.26 \mathrm{~b}$ & $2.22 \mathrm{cdef}$ & $8.48 \mathrm{~d}$ & $761 \mathrm{~d}$ \\
& $\mathrm{~T}_{6}$ & $3.99 \mathrm{abc}$ & $6.40 \mathrm{~b}$ & $2.36 \mathrm{bcdef}$ & $8.76 \mathrm{bcd}$ & $833 \mathrm{~cd}$ \\
& $\mathrm{~T}_{7}$ & $2.45 \mathrm{e}$ & $7.52 \mathrm{a}$ & $2.61 \mathrm{bc}$ & $10.13 \mathrm{~b}$ & $901 \mathrm{~cd}$ \\
\hline
\end{tabular}

${ }^{*}$ Means, in each column, followed by similar letter are not significantly different at the $5 \%$ probability level-using Duncan's Multiple Range Test. $\left(\mathrm{T}_{1}\right.$, $\mathrm{T}_{2}, \mathrm{~T}_{3}$ : Pretreatment of seeds in $15 \mathrm{mT}$ for 5,15 and 25 minutes, $\mathrm{T}_{4}, \mathrm{~T}_{5}, \mathrm{~T}_{6}$ : Pretreatment of seeds in $25 \mathrm{mT}$ for 5,15 and 25 minutes, $\mathrm{T}_{7}: 3 \mathrm{mT}$ continuous magnetic field and $\mathrm{T}_{8}$ : Control)

seeds previously treated in a stationary magnetic field of 1-10 $\mathrm{mT}$ germinated earlier than the untreated seeds, that it could be due to an increase in rate of water uptake. Martinez et al. (2009) reported that MGT were decreased by exposing of tomato seeds to magnetic field. They were added that the maximum effect of magnetic field achieved in $250 \mathrm{mT}$ at 24 hours and continuous exposure. Vashisth and Nagarajan (2010) displayed that magnetic field enhanced germination rate of sunflower seeds. They stated that earlier germination that led to improvement of seed vigor and superior root traits may be is due to more activity of hydrolyzing enzymes.

The highest root, shoot and seedling length were achieved in $3 \mathrm{mT}$ continuous magnetic field treatment. Also exposure of seeds in $25 \mathrm{mT}$ magnetic field had the highest root and seedling length compared to other treatments. It seems that improvement of root and shoot length in magnetic treatments led to increase the seedling length. Continuous magnetic field increased seedling length nearly by 33 percent while $25 \mathrm{mT}$ at 5 minutes treatment increased seedling length by 25 percent compared with control (Tab. 3). It has been reported that magnetic field promotes the enzyme activities such as $\alpha$-amylase, dehydrogenase and protease in seed (Vashisth and Nagarajan, 2010). De Souza et al. (2006) indicated that mean fruit weight, fruit yield and biological yield of tomato were increased when the seeds treated with magnetic field. Increasing of germination rate, shoot fresh weight and seedling length on maize has been reported when the seeds exposure to magnetic field (Florez et al., 2007; Racuciu et al., 2006). Van et al. (2011) reported that the magnetic field of $0.1 \mathrm{~T}$ resulted in the greatest fresh weight of regenerated protocorm-like bodies of orchid micropropagation.
Interaction effect between seed bydro priming and magnetic field

The lowest MGT was obtained in both of hydro primed and dry seeds in $3 \mathrm{mT}$ continuous magnetic field (T7). Mean germination time was reduced by 63.5 and 60 percent when hydro primed and dry seeds exposed to 3 $\mathrm{mT}$ continuous magnetic field, respectively. Root length increased by 29 and 25 percent in $3 \mathrm{mT}$ continuous magnetic field and $25 \mathrm{mT}$ at 5 minutes compared with control, respectively. The highest shoot length, seedling length and vigor index were observed in $3 \mathrm{mT}$ continuous magnetic field and $25 \mathrm{mT}$ at 5 minutes treatments (Tab. 4). It has been reported that root formation increased by nearly 25 and $40 \%$ at initiated root growth and 6 days seedlings displayed stages, respectively, when wheat seeds treated at 15 min by $30 \mathrm{mT}$ magnetic field followed by $17 \mathrm{~h}$ imbibitions in the water (Aksyonov et al., 2001). Vashisth and Nagarajan (2010) revealed that shoot length (4-41\%), root length (16-80\%), seedling length (12-57\%) and vigor index (18$74 \%)$ of sunflower were increased at different magnetic fields compared with control treatment.

\section{Conclusions}

Exposure of hydro primed and dry tomato seeds to static magnetic fields significantly improved mean germination time, root, shoot and seedling length and vigor index compared to unexposed control treatments. Among the various combinations of magnetic fields and duration, $3 \mathrm{mT}$ continuous magnetic field and $25 \mathrm{mT}$ for 5 minutes exposure yielded superior results. The improved functional root parameters indicate that magnetically treated tomato seeds can be used in agriculture under direct seeding 
120

farming in open field tomato production system, where better root growth will enable earlier seed emergence and improved field establishment.

\section{References}

Anonymous (2007). Iran annual agricultural statistics. Ministry of Jihad-e-Agriculture of Iran, www.maj.ir.

Aksyonov SI, Bulychev AA, Grunina T ( 2001). Effects of ELF-EMF treatment of wheat seeds at different stages of germination and possible mechanism of their origin. Electromag Biol Med 20:231-253.

Aladjadjiyan A (2002). Study of the influence of magnetic field on some biological characteristics of Zea mays. J Central Eu Agric 3:89-94.

Aladjadjiyan A (2010). Influence of stationary magnetic field on lentil seeds. Int Agrophysics 24:321-324.

Cakmak T, Dumlupinar R, Erdal S (2009). Acceleration of germination and early growth of wheat and bean seedlings grown under various magnetic field and osmotic conditions. Bioelectromag 30:1-10.

Celestino C, Picazo ML, Toribio M ( 2000). Influence of chronic exposure to an electromagnetic field on germination and early growth of Quercus suber seeds: preliminary study. Electro Magnetobiol 19:115-120.

De Souza A, Garcí D, Sueiro L, Gilart F, Porras E, Licea L (2006). Pre-sowing magnetic treatments of tomato seeds increase the growth and yield of plants. Bioelectromag 27:247-257.

Dhawi F, Al-Khayri JM, Hassan E (2009). Static magnetic field influence on elements composition in date palm (Phoenix dactylifera L.). Res J Agric Biol Sci 5:161-166.

Faqenabi F, Tajbakhsh M, Bernooshi I, Saber-Rezaii M, Tahri F, Parvizi S, Izadkhah M, Hasanzadeh Gorttapeh A, Sedqi H (2009). The effect of magnetic field on growth, development and yield of safflower and its comparison with other treatments. Res J Agric Biol Sci 4:174-178.

Florez M, Carbonell MV, Martinez E (2007). Exposure of maize seeds to stationary magnetic fields: Effects on germination and early growth. Environ Exp Botany 59:68-75.
Garcia Reina F, Pascual LA, Fundora IA (2001). Influence of a stationary magnetic field on water relations in lettuce seeds. Part II: Experimental Results. Bioelectromag 22:596-602.

Harichand KS, Narula V, Raj D, Singh G (2002). Effect of magnetic fields on germination, vigour and seed yield of wheat. Seed Res 30:289-293.

ISTA (2009). ISTA rules. International Seed Testing Association. Zurich, Switzerland.

Martinez E, Carbonell MV, Amaya JM, Maqueda R (2009). Germination of tomato seeds (Lycopersicon esculentum L.) under magnetic field. Int Agrophysics 23:45-49

Matthews S, Khajeh-Hosseini M (2007). Length of the lag period of germination and metabolic repair explain vigour differences in seed lots of maize (Zea mays). Seed Sci Technol $35: 200-212$

Podlesny J, Pietruszewski S, Podleoen A (2004). Efficiency of the magnetic treatment of broad bean seeds cultivated under experimental plot conditions. Int Agrophysics 18:65-71.

Racuciu M, Creanga D, Horga I (2006). Plant growth under static magnetic field influence. Ro J Physics 53:353-359.

Van PT, Teixeira da Silva JA, Ham LH, Tanaka M (2011). Effects of permanent magnetic fields on the proliferation of Phalaenopsis protocorm-like bodies using liquid medium. Sci Hortic 128:479-484

Vashisth A, Nagarajan S (2008). Exposure of seeds to static magnetic field enhances germination and early growth characteristics in chickpea (Cicer arietinum L.). Bioelectromag 29:571-578.

Vashisth A, Nagarajan S (2010). Effect on germination and early growth characteristics in sunflower (Helianthus annuus) seeds exposed to static magnetic field. J Plant Physiol 167:149-156 